field of international affairs should make an important contribution to the development of a real international society by assisting the removal from international law of some of these imperfections and immaturities in regard to treaties.

\section{Further Amendments to the Pharmacopœia}

FUrther amendments, due to conditions arising out of the prosecution of the War, have been made to the "British Pharmacopœia". They have been made effective by notices in the Gazettes. Owing to the closing of the principal source of supply of squill, namely Sicily, sanction is now given for the use of Indian squill (Urcinea indica) in place of Urcinea scilla in the preparation of oxymel, vinegar and tincture of squill. In the case of valerian, which was formerly obtained chiefly from Belgium, Holland and Germany, the use is now permitted of Indian valerian (Valeriana wallichii) in place of Valeriana officinalis whenever valerian is prescribed or demanded. Another amendment sanctions the use of sodium lactate instead of glycerin in the preparation of poultice of kaolin, the object being to assist in the conservation of supplies of glycerin. Facilities have been given by the appropriate Government departments for the importation of Indian squill and Indian valerian.

\section{Institute of Chemistry}

AT the annual general meeting of the Institute of Chemistry held on March 3, the president, Dr. J. J. Fox, C.B., the Government Chemist, presented the report of the Council, in the course of which he stated that the professional examinations of the Institute had contiaued, and the membership had increased by more than 220 during the year. The increase in the numerical strength of the Institute since 1914, he said, has been remarkable; it has been multiplied more than five times, namely, from 1,454 to 7,775 . In the meantime, unemployment among the members has never exceeded 3 per cent and at the present time is less than 1 per cent. Industry was far more fully staffed with chemists in September 1939 than in July 1914, but the Institute had been of much assistance to the Government in supplying chemical personnel during the War. Dr. J. J. Fox was reelected president; and the Meldola Medal for 1940 was awarded to Dr. E. R. H. Jones, assistant lecturer in organic chemistry in the Imperial College of Science and Technology.

\section{Food in War-time}

An important article, "Food in War Time", by Lord Horder in the Quarterly Review of January emphasizes the way in which food policy in war could be utilized to make a permanent contribution to national fitness, and the part which science has to play in pursuing this objective. Science, Lord Horder points out, supports a return to the diet that kept our fathers and forefathers fit, and assures us that in doing so we are on sound and rational lines. The memorial sent to the Prime Minister last May, of which Lord Horder was a signatory, urged that milk, potatoes, fresh vegetables, cereals, fats and sugar, should be kept constantly in mind as the basis of fitness. The whole consumption of the first three could be grown at home, and better use of our homegrown fruit would enable us to reduce considerably our imports of fruit. We could grow all the oats we need and much more of the wheat and barley.

A comprehensive food policy connotes close and constant co-operation between the Ministries of Food, Agriculture and Transport ; intelligent co-operation on the part of the consumer is essential to success in a campaign for feeding the people properly in wartime, and Lord Horder pleads for greater use of the educational opportunities given by war-time conditions. By planning wisely we could rapidly enable the town worker to retrace his steps in the matter of diet, making more accessible the wholesome foods which his ancestors ate and which he discarded when he became urbanized, and at the same time making less available the more unsuitable foods which have taken their place for the last two generations. In such planning the Minister of Food has the guidance and backing of science and medicine, and this contribution to building a better social and economic system could start now.

\section{Merseyside Naturalists' Association}

Ax the third annual meeting of the Merseyside Naturalists' Association, held at the Liverpool Museum on February 23, Mr. R. K. Perry, keeper of vertebrates at the Museum, was elected president, Dr. J. C. P. Miller of the University of Liverpool, chairman, and Mr. Eric Hardy, honorary secretary. Since 1939 membership and funds have doubled, activities have been continued in full, with a wellattended programme of meetings; additions to the local flora have been made to the national herbaria at Kew and the British Museum. The president exhibited a collection of skins of rare British mammals, detailed reports were presented of bird surveys at Leigh Flashes, Rufford, Puffin Island, the Great Orme's Head, C'orwen, etc., and the MS. of the Association's proposed handbook on the birds of the area. As this is by far the largest natural history society in the area it was agreed to continue activities so far as the War permitted.

\section{American Geographical Society: Medal Awards}

Two medals have recently been awarded by the American Geographical Society. Dr. R. C. Murphy, of the American Museum of Natural History, receives the Cullum Geographical Medal for distinguished work on the migration and habits of oceanic birds, which are his speciality. $\mathrm{He}$ is the first ornithologist to receive this medal, which has previously been awarded thirty-five times. Earlier recipients have included Admiral Robert E. Peary, Sir John Murray and Prince Albert of Monaco. Prof. C. O. Sauer, of the University of California, receives the Charles P. Daly Medal, in recognition of his outstanding contributions to geography, especially in the fields of land classification and land utilization. Among the twenty-nine recipients of the Daly Medal have been Vilhjalmur Stefansson, Capt. Robert A. Bartlett and Dr. Roy Chapman Andrews. 